\title{
Legal education and the legal profession
}

Citation for published version (APA):

de Groot, R. (1993). Legal education and the legal profession. In J. Chorus (Ed.), Introduction to Dutch Law for Foreign Lawyers (pp. 27-31). Springer.

Document status and date:

Published: 01/01/1993

Document Version:

Publisher's PDF, also known as Version of record

\section{Please check the document version of this publication:}

- A submitted manuscript is the version of the article upon submission and before peer-review. There can be important differences between the submitted version and the official published version of record.

People interested in the research are advised to contact the author for the final version of the publication, or visit the DOI to the publisher's website.

- The final author version and the galley proof are versions of the publication after peer review.

- The final published version features the final layout of the paper including the volume, issue and page numbers.

Link to publication

\footnotetext{
General rights rights.

- You may freely distribute the URL identifying the publication in the public portal. please follow below link for the End User Agreement:

www.umlib.nl/taverne-license

Take down policy

If you believe that this document breaches copyright please contact us at:

repository@maastrichtuniversity.nl

providing details and we will investigate your claim.
}

Copyright and moral rights for the publications made accessible in the public portal are retained by the authors and/or other copyright owners and it is a condition of accessing publications that users recognise and abide by the legal requirements associated with these

- Users may download and print one copy of any publication from the public portal for the purpose of private study or research.

- You may not further distribute the material or use it for any profit-making activity or commercial gain

If the publication is distributed under the terms of Article $25 \mathrm{fa}$ of the Dutch Copyright Act, indicated by the "Taverne" license above, 


\section{Chapter 4. Legal education and the legal profession ${ }^{1}$}

\section{G.R. de Groot}

\section{Basic legal education}

Basic legal education in the Netherlands, which provides the qualifications necessary to enter into a legal profession, is provided exclusively by universities. There is no centrally-organized, state examination for admission to any of the legal professions. Moreover, each university conducts its own examination independently; in particular there is no supervision of one university's examinations by external examiners from other universities.

Currently, nine law faculties have the power to confer a law degree: the University of Amsterdam, the Free University (Amsterdam), the University of Groningen, the University of Leyden, the University of Limburg (Maastricht), the Catholic University of Nijmegen, the Erasmus University (Rotterdam), the Catholic University of Brabant (Tilburg) and the University of Utrecht. In addition the Open University (Heerlen) is developing a legal curriculum.

There is no selection procedure for admission to a law faculty. Everybody who has a $\mathrm{VWO}^{2}$ certificate may be admitted to read law. The aspiring student applies to a centrall admissions office which decides at which university the student may enroll. A student is allocated to a particular university according to his or her expressed preference, taking into account the student's economic and social connections with a certain region of the country. There is no official ranking of the universities.

Law faculties have considerable autonomy in regulating their curricula, and Ministry of Education specifications as to the contents of the law curriculum are phrased in very general terms. These two factors have as a result that the curricula of the law faculties are rather disparate, thus trammelling the opportunity for students to switch universities during their studies. The Ministry of Education regulations require a law curriculum to be four years in length.

The curriculum is divided into two parts by the selective propaedeutic examination which takes place after the first year. Students who pass the propaedeuse are permitted to continue studying for the final doctoraal degree. Both propaedeuse and doctoraal examinations are examined in stages, after each course or group of courses; these examination stages are called tentamens. Art. 82 of the Royal Decree on university education (Academisch Statuut) provides that the propaedeutic examination must contain the following subjects: legal theory, constitutional or

1. In the first edition of thas publication this chapter was written by G.W.M. Bodewes, judge at the arrondissementsrechbbank Haarlem. C.f. Julian Lonbay: Report on the professional qualifications of the legal profersions in the civil late jurisdictions of the European Cammunities, Institute of European Law, University of Birmingham, 1990, for an extensive review of legal education in the Netherlands.

2. Voorbereidend wetenschappelijk onderwijs $s_{x}$ comparable with English A-levels. 
administrative law, criminal law and private law. Furthermore, economics and history of law can be part of the propaedeutic examination.

After the propaedeutic examination most students opt for the Dutch law programme (studierichting Nederlands recht). The final (doctoraal) examination of this programme is the basic prerequisite for the position of judge, public prosecutor or advocaat. ${ }^{3}$ Art. 83 of the Academisch Statuut provides that this doctoral examination must contain constitutional and administrative law, criminal law and private law. For all these subjects knowledge of procedural law must also be cxamined. Furthermore, unless economics and history of law were already taken in the propaedeutic examination, a candidate has to be examined on these subjects in the doctorad examination. In addition a student has to take one philosophical or sociological subject and one international or comparative subject. The successful doctorad candidate does not obtain the degree of doctor, but the degree of a magister iuris (meester in the rechten; master of laws; abbreviated, for both male and female candidates, to $m r$.).

Most faculties offer a range of alternatives to the Dutch law programme. Three other law programmes entitle the successful candidate to the degree magister iuris: ${ }^{4}$ the notarial programme (for those intending to become a notaris), the fiscal-juridical programme (for intending tax-law specialists) and finally the Antillian or Aruban law programme (for intending specialists in the law of the Dutch Antilles or Aruba). The title magister iuris acquired by following one of these three programmes is not a qualification to become a judge, public prosecutor or advocaut in the Netherlands. In addition to the above-mentioned programmes there are programmes in, inter alia, international law or the free programme. ${ }^{5}$ Success in the doctoraal examinations in these programmes does not entitle the degree magister iuris to be conferred, but the degree doctorandus iuris (abbreviated $d r s)^{6}$

\section{Academic career}

A successful doctoraal candidate may subsequently study for the degree of doctor (abbreviated $d x$ ) by writing a doctorate thesis (called proefschrift or dissertatie), which requires a considerable amount of research and usually takes several years. The thesis has to be published, and, only after publication, has to be defended in a ceremonial academic session of the faculty. A candidate for this research degree need not be in post at a university, but there is a recent tendency for candidates to write their thesis while appointed as assistent in opleiding (junior researcher; abbreviated aio). This appointment is limited to a period of four years, with the possibility of a one year extension.

3. Art. 2 Act on adpocaten of 23 Jun 1952, Stb. 365 (Adoocatenuet); Arrs. 35, 48, $59 \mathrm{~b}, 62$, 86 Act on the judicial organization (Wet of the rechterlyke organisatie).

4. Art. 72 Academisch Statut; sief further Arts. 84-87, 95, 95 Acadomisch Stalutut.

5. C.f. Arts. 88-93 Academisch Staturt.

6. Dotorandus is the degree which is most commonly obtained by those who successfully complete a uniwersity study in the Netherlands.

7. It is remarkable that most doctors in law in practice only use the title of mr. (magister iuris) and not the rivle of doctor. 
The three grades of academic status, apart from the just mentioned post of junior researcher, are, in progressive order of seniority: university lecturer ${ }^{8}$ (universitair docent, abbreviated udi), senior lecturer (universitair hoofddocent; abbreviated uhd) and professor (hoogleraar). University lecturers, frequently, but not always, have tenure. It is an official rule of the Ministry of Education that persons appointed to any of these three university posts already have the degree of doctor. In fact this rule is honoured more in the breach than in its observance, for the majority of university lecturers are still working to attain the degree of doctor. In the Netherlands only the hoogleraar has the right to use the title professor. Moreover, the Dutch system of legal education has no stage comparable to the French agrégation or the German Habilitation. ${ }^{10}$ Every doctor is eligible to be appointed as professor. Even without the degree of doctor, as in the case of a person with long professional experience as a legal practitioner or judge combined with a weighty publication record, an appointment to professorship is possible.

\section{The Judiciary}

A successful candidate in the doctoraal examination may apply for a position as candidate judicial officer (rechterlijk ambtenaar in opleiding, abbreviated raio)." Only candidates with very high examination results are selected for these positions. During a training period of six years a candidate judicial officer is employed at the court (as a judge's assistant), at the office of the public prosecutor and at the bar, in order to acquire practical experience. During this period the candidate judge does not have to pass examinations, but might be advised to terminate the training. After a successful training of six years the candidate is eligible to be appointed judge (rechter) ${ }^{12}$ or public prosecutor (officier van justitie). Approximately $50 \%$ of the judiciary come into post via this route. The remainder are appointed after having practised as advocaten, company lawyers, civil servants or university teachers.

Higher-level judicial appointments, to the post of kantonrechter (in the kantongerecht ${ }^{13}$ ) or the post of raadsheer (in the gerechtshof ${ }^{14}$ and the Hoge Raad ${ }^{15}$ ), are made either from the pool of practising judges or by appointing individuals direct from legal practice or from universities. In the event of appointment direct from legal practice or academic life appointment is usually preceded by several years of part-time practice as a substitute judge (rechter-plaalsvervanger).

8. In the U.S.A. the equivalent is an assistant professor.

9. In the U.S.A. the equivalent is an associate professor.

10. These are degrees which can be obtained after completing the doctorate.

11. Besluit opleiding rechterlijte ambtenaren of $24 \mathrm{Oct} 1985, \mathrm{Stb} .555$.

12. Even though the kantongerecht is the lowest instance court, nomally the first appoimtment will be as judge in the arrondissementsrechtbank. Because the kantonechter sits alone, the latter is considered an
unsuitable task for a newly-appointed judge.

113. The lowest level court for civil and criminal matters.

14. The appeal court to which an appeal on a question of law or fact may be taken.

15. The highest court to which appeals on any question of law may be taken. 


\section{Legal practitioners: the advocaat}

The successful candidate of the Dutch law programme's doctoraal examination who wishes to become an advocaat must apply for membership of the Netherlands Bar Association (Nederlandie Orde van Advocaten). It is a pre-condition for admission to this society that the candidate has been examined in, and graduated on the basis of: Dutch private and commercial law, criminal law, and one of the following three subjects: Dutch constitutional law, administrative law or taxation law. In the first three years after admission the fledgling advocaat has to practise under the supervision of an advocaat of at least seven years" standing. Furthermore, before being able to practise without supervision, the traineeadvocaat has to follow courses and pass examinations in practitioner-relevant subjects such as evidence and legal drafting. ${ }^{16}$

Almost every adtacaat is simultaneously a procureur. The role of the procureur is to sign documents in civil cases and deal with formal aspects of civil procedure. A procureur is always attached to, although not employed by, a district court (arrondissementsrechtbank) and can only act within that district. An advocaat can act in other districts as well, but in such cases a local procureur must introduce him formally to the court. This local procureur also has to sign all the documents written by the adrocaat and has to send them to the court. In criminal cases the division between the function of advacaat and procureur does not exist. The qualifications required for admission to the position of procureur are the same as those for the position of advocaat. ${ }^{17}$

Advocaten have no legal monopoly on the giving of legal advice. Accordingly it is permissible for individuals to work as legal advisors (rechtskundig adviseur), without having any academic degree or other qualification. The absence of a monopoly on the giving of legal advice is conducive to the development of law centres (rechtswinkels), which are often sponsored by legal faculties and staffed by unqualified law students. Moreover, in courts, such as the kantongerechten, in which advocaten/procureurs do not have a monopoly with respect to legal representation, legal advisors are permitted to represent clients before the court. ${ }^{18}$

Out of court, the advocaat/procureur's right-hand-man is the bailiff (deurwaarder), one of whose functions is to serve upon a defendant the summons or original application requiring the defendant to appear before the court or a summons requiring payment. The deurwaarder, who does not have a university education, but will have successfully completed a state examination, ${ }^{19}$ has a variety of functions. ${ }^{20}$ In court the detrwaarder serves as an usher. Furthermore, he en-

16. Art. 9 b Adwocatenwet; see further the Stageserordening 1988 , Stcrt. 1988, 127 enacted by the Netherllands Bar Association and Examenteglement beropsopleiding of 4 Jul 1938, Adwocatenblad 1988, pp. 19-21, amended 8 May 1989, Adoncatenblad 1989, p. 328.

17. Art. 64 Adivocitenwet.

18. The position of these legal advisors should be compared with the very restricted powers of Mackentie advisors under English law, who are not permitted to address the court, but only to sit beside the client and advise about the conducting of the case.

19. Art. 34 Dounvoundersreglement, KB 27 Dec 1960, Stb. 562.

20. $C . f$. Art. 14 and 26 Deuneaardersteglement. 
forces judgments and notarial deeds. In the exercise of this function the deurwaarder is empowered to seize movables and sell them by public auction in order to obtain payment for the creditor. But the powers of the deurwaarder are limited to movable property; the enforced selling of real estate has to be done by a notaris. Finally, it is not uncommon for a deurwaarder to give legal advice in straightforward cases or to represent litigants before the kantongerecht.

\section{Legal practitioners: the notaris}

The Netherlands counts amongst those countries with a Latin notarial tradition. ${ }^{21}$ The Dutch notaris is a more important functionary than the notary which occurs in common law countries, where most of the functions performed by the Latin notaris are performed by other legal practitioners. A notaris is appointed by the Crown. He or she is not, however, a government employee, but rather charges clients direct for services, the most important of which have fixed rates. The notaris has a life appointment which can only be terminated for reasons provided by law. This legal practitioner is a vital functionary in the administration of justice and can be compelled to render his or her services.

A person who wishes to be eligible for appointment as a notaris must, having obtained the doctoraal examination after following the notarial programme, ${ }^{22}$ acquire at least three years" training as apprentice-notaris (kandidaat-notaris) in the office of a notaris. During this apprenticeship the apprentice-notaris has to follow special practitioner courses. Because the number of positions available for notarissen is limited to approximately one thousand a candidate may have to wait many years before being appointed as notaris. A notaris has a monopoly in relation to, inter alia, last wills, marriage contracts, the transfer and mortgage of real estate and the establishment of corporate status. ${ }^{23}$

21. The same practice exists in France, Belgium, Luxembourg, Italy, Spain, Greece, in most countries of Latin America and in a part of Germany.

22. C.f. Art. 20 a Wet op het notarisambt of $9 \sqrt{\mathrm{a}} \mathrm{ul} 1842$, Stb. 20. 23. I wish to thank my colleagues of the University of Limburg, Caroline Fonder, LL. B (Notim.),
LL.B (Cantab.), and Ass. itar. Hildegard Schnieder for their critical conments on carlier versions of
this text. 